\title{
New Identity: Becoming a Buddhist in Banyumas, Indonesia, 1965-1980s
}

\author{
Puji Sulani ${ }^{1}$, Priyanto Wibowo ${ }^{2}$ \\ \{puji.sulani@ui.ac.id ${ }^{1}$, priyanto.wibowo13@gmail.com² ${ }^{2}$, \\ Fakultas Ilmu Pengetahuan Budaya, Universitas Indonesia, Depok, Indonesia ${ }^{12}$
}

\begin{abstract}
The followers of local belief (aliran kepercayaan) in Banyumas, Indonesia, were converted to Buddhism between 1965-1980s. This paper discusses the identity changes of the followers of those beliefs in Banyumas into Buddhism in that period. The phenomenon was analyzed using social history approach to understand how the Javanese community in Banyumas constructed their new religious identity. The main finding of this study shows that religious politics and political conflicts during the Old Order to the New Order era were the main causes of their conversion. The argument proposed in this paper is that the religious conversion was an effort to make positioning of their struggle against communist stereotype after the September $30^{\text {th }}$ Movement of 1965.
\end{abstract}

Keywords: religious identity, religious conversion, communist stereotype, Javanese Buddhist.

Identitas Baru: Menjadi Umat Buddha di Banyumas, Indonesia, 1965-1980-an

\begin{abstract}
Abstrak. Pengikut aliran kepercayaan di Banyumas, Indonesia, melakukan konversi ke agama Budha antara 1965-1980-an. Tulisan ini mendiskusikan perubahan identitas aliran kepercayaan di Banyumas ke agama Budha pada periode tersebut. Fenomena ini dianalisis melalui pendekatan sejarah sosial untuk mengetahui upaya masyarakat Jawa di Banyumas dalam memperoleh identitas agama baru mereka. Temuan utama studi ini menunjukkan bahwa politik agama dan konflik politik selama masa Orde Lama hingga Orde Baru menjadi penyebab utama konversi agama mereka. Argumen dalam tulisan ini adalah bahwa konversi agama merupakan upaya pemosisian untuk melawan stereotip komunis pasca-Gerakan 30 September 1965.
\end{abstract}

Kata kunci: identitas agama, konversi agama, stereotip komunis, Budha Jawa.

\section{Pendahuluan}

Peristiwa Gerakan 30 September 1965 (G30S) berdampak pada perubahan sosial dan politik. Penyelesaian peristiwa tersebut menjadi titik pertemuan antara upaya pembersihan komunis dengan pemberlakuan kebijakan terkait agama melalui Penetapan Presiden Nomor 1/PNPS/1965 tentang Pencegahan Penyalahgunaan dan/atau Penodaan Agama. Peristiwa G30S juga berdampak terhadap kehidupan agama masyarakat Jawa, terbukti dengan adanya peningkatan jumlah penganut agama formal pada 1966-1969 [1]. Jumlah penganut Hindu dan 
Budha mengalami peningkatan dari $1 \%$ menjadi 4\% [2]. Perubahan agama masyarakat Jawa sebelumnya telah terjadi pada abad 15, yaitu dari Hindu dan Budha ke agama Islam, serta pada awal abad 19 dengan munculnya penganut agama Kristen akibat pengaruh kedatangan Belanda [3]. Masyarakat Jawa di wilayah Banyumas, Jawa Tengah, pada awal abad 20 terbagi menjadi penganut agama Islam, Kristen, Katolik, dan Konghucu, di samping praktik agama lokal, dengan bukti adanya sarana peribadatan masing-masing agama [4]. Perubahan agama masyarakat Jawa mengikuti perubahan budaya, sosial, dan politik lokal maupun nasional.

Agama lokal masyarakat Jawa sebagai "tindakan religius Jawa" merupakan bagian dari pencarian identitas spiritualitas individu [5]. Spiritualitas masyarakat Jawa di wilayah Banyumas memiliki keunikan, selaras identitas budayanya yang "marginal atau tanggung kejawaan dan kesundaannya," [6] yaitu tercampur dengan spiritualitas lokal yang direpresentasikan melalui Islam Aboge dan Islam Bonokeling. Agama lokal masyarakat saat ini kembali berkembang. Namun, pada akhir tahun 1960-an hingga 1980-an terjadi pembekuan kelompok aliran kepercayaan, sehingga cukup beralasan untuk mempertanyakan, ke mana dan agama apa yang dianut oleh pengikut aliran kepercayaan tersebut? Adakah yang menjadi penganut agama Budha? Terlebih sejak kemunduran kerajaan Hindu dan Budha, agama yang diakui adalah Islam, Kristen, dan Katolik, meskipun terdapat praktik agama lokal.

Pada akhir tahun 1967 penganut Hindu dan Budha di Jawa mengalami peningkatan sebesar 3\%. Antara tahun 1975 hingga 1978 terdapat 21 tempat peribadatan Budha di Jawa Tengah [7]; tiga di antaranya dibangun di Banyumas dan Cilacap pada tahun 1967-1971 [8]. Tempat peribadatan Budha di Jawa Tengah sejak tahun 1979 mengalami peningkatan dari 23 menjadi 38 pada tahun 1980 dan menjadi 39 buah pada tahun 1981. Berdasarkan jumlah penganutnya, pada tahun 1980 di Jawa Tengah terdapat penganut agama Budha berjumlah 138.074 jiwa [9]. Fenomena tersebut menunjukkan perubahan identitas agama masyarakat Jawa pasca-G30S 1965 hingga tahun 1980-an. Hal ini juga menimbulkan pertanyaan, karena agama yang berkembang hingga awal abad 20 adalah Islam, Kristen, dan Katolik, sedangkan Budha muncul pada tahun 1930-an di perkotaan. Kapan dan mengapa sebagian masyarakat Jawa ini menganut agama Budha? Apakah ada keterkaitan antara peristiwa G30S dan pembekuan aliran kepercayaan dengan perubahan tersebut?

Masyarakat pedesaan di wilayah Banyumas yang melakukan konversi agama ke Budha pasca-G30S 1965 berasal dari pengikut kepercayaan Kawruh Naluri dan Sapto Darmo, serta Islam (abangan). Umumnya, mereka tinggal berkelompok di satu atau beberapa dusun di desa tertentu. Jumlah penganut Budha pada masa awal konversi cukup signifikan, kurang lebih sebanyak 400 orang. Keberadaan penganut Budha yang hidup berkelompok pada beberapa dusun dalam satu atau beberapa desa di wilayah Banyumas, serta belum adanya kajian dampak peristiwa 1965 terhadap perubahan identitas agama masyarakat Jawa ke agama Budha, melatarbelakangi dilakukannya studi ini. Tujuan studi ini adalah untuk merekonstruksi alasan masyarakat eks-pengikut aliran kepercayaan memilih identitas agama Budha.

\section{Metode}

Studi ini menggunakan pendekatan sejarah sosial. Metode sejarah lisan digunakan dalam pengumpulan data, kritik sumber, interpretasi, dan penulisan fakta sejarah. Sumber utama berasal dari pelaku dan saksi sejarah konversi aliran kepercayaan menjadi Budha di Banyumas, Jawa Tengah. Informasi yang diperoleh dianalisis menggunakan pendekatan sejarah sosial dengan menerapkan konsep identitas budaya Hall (1990), bahwa identitas 
merupakan sebuah proses untuk "menjadi" (becoming) dan bukan sekadar "keberadaan" (being), serta digunakan untuk "memosisikan" (positioning) dan "diposisikan" (positioned) dalam narasi masa lalu [10]. Selain itu, digunakan juga pemikiran Berger \& Luckmann (1991), bahwa perubahan sosial merupakan hasil konstruksi sosial secara dialektik melalui eksternalisasi, objektivasi, dan internalisasi [11].

\section{Hasil dan Pembahasan}

Perubahan identitas agama masyarakat pedesaan Jawa dengan menjadi penganut agama Budha terjadi sebagai sebuah evolusi. Peristiwa G30S dan upaya pembersihan komunis di masyarakat pedesaan, bersamaan dengan pemberlakuan Penpres Nomor 1/PNPS/1965 tentang Pencegahan Penyalahgunaan dan/atau Penodaan Agama, menjadi salah satu penyebab perubahan identitas agama. Dampaknya, penganut agama formal dan aliran kepercayaan memilih untuk memiliki identitas baru; salah satunya sebagai pemeluk agama Budha. Data awal abad 21 memberikan gambaran keberadaan penganut Buddha di wilayah Banyumas, dengan jumlah 2.205 jiwa. Mereka terdistribusi di empat kecamatan, yaitu 311 orang di Kecamatan Kebasen, 127 orang di Kecamatan Kemranjen, 681 orang di Kecamatan Sumpiuh, dan 117 orang di Kecamatan Tambak [12]. Mereka merupakan eks-penganut agama Islam dan pengikut aliran kepercayaan Kawruh Naluri dan Sapto Darmo. Salah seorang informan, Suminah, menyatakan: "Di sini adanya ialah Kawruh Naluri Alam." Adapun Kastam, informan lain, menyatakan: "Dulu itu Sapto Darmo di sini termasuk banyak, sebelum ada pembinaan itu." Berdasarkan latar belakang organisasi sosial dan politik, sebagian besar berasal dari keluarga eks-simpatisan Partai Komunis Indonesia (PKI) dan simpatisan Partai Nasional Indonesai (PNI), di samping para korban stereotip komunis.

Masyarakat yang menjalankan praktik spiritual Jawa atau agama lokal dianggap "belum beragama" [13] karena keyakinan mereka dianggap belum memenuhi kriteria agama, dan praktik keagamaannya pun bertentangan dengan agama formal. Standarisasi agama menjadi dasar pengategorian agama dan bukan agama terhadap kehidupan spiritual masyarakat yang tidak atau kurang taat beragama, serta yang dalam hal organisasi politik dianggap sebagai representasi komunis dan nasionalis. Keluarga Suminah merupakan penganut Kawruh Naluri dan simpatisan PNI: "Kita di sini PNI, yang bajunya merah, simbolnya banteng, ya Bapak di sini ya aktif." Lebih lanjut, Suminah menyampaikan bahwa "Setelah tahun '65 ada G30S, kita takut paham kita dikira itu (komunis), jadi kita usaha bagaimana untuk supaya bebas dari G30S." Adapun Kastam menjelaskan bahwa "Timbul perbedaan pendapat antara lingkungan dan pemerintahan bahwa Sapto Darmo bukan agama, maka pada tahun ' 67 hingga ' 70 -an ada instruksi presiden bahwa harus masuk agama, sehingga penganut kepercayaan menjadi penganut agama Budha." Pernyataan Suminah dan Kastam menunjukkan adanya ancaman sosial "dianggap komunis" di masa itu. Kondisi ini menimbulkan stereotip komunis yang secara tidak langsung dianggap "tidak beragama." Stereotip komunis pasca-G30S menjadi alasan bagi para pengikut aliran kepercayaan Kawruh Naluri dan Sapto Darmo untuk mencari identitas agama baru. Peristiwa G30S dan kebijakan negara yang mengharuskan setiap warga negara memeluk salah satu agama menjadi sebab kuat terjadinya perpindahan agama. Sebagian pengikut aliran kepercayaan ini berlindung ke naungan agama Budha dengan mengubah identitas menjadi umat Budha. Perubahan dilakukan atas seruan pemerintah desa sebagaimana diungkapkan Kastam. Proses perubahan identitas agama dilakukan melalui upacara peresmian agama di masing-masing desa yang dihadiri oleh pemerintah desa dan 
Koramil. ${ }^{\text {s }}$ Upacara ini merupakan bentuk legitimasi dan "perlindungan" terhadap identitas baru masyarakat.

Dalam memilih identitas baru dengan menjadi penganut agama Budha, masyarakat pengikut aliran kepercayaan Kawruh Naluri dan Sapto Darmo memiliki beberapa alasan berdasarkan latar belakang budaya Jawa maupun praktik spiritual mereka. Suminah sebagai representasi pengikut Kawruh Naluri memilih agama Budha karena sumber ajaran yang diikuti di Gombong adalah Budha. Puriyan menyatakan bahwa agama Budha menjadi pilihan karena arahan dari pimpinan aliran kepercayaan Kawruh Naluri di Gombong. Kastam menjelaskan bahwa keluarganya dan masyarakat sekitar memilih Budha karena leluhur mereka penganut Budha. Identitas agama Buddha diperoleh ketika pemimpin kelompok mencari sumber ajaran agama Budha. Konversi agama mereka kemudian diresmikan di hadapan pemerintah lokal. Dalam proses konstruksi identitas barunya, eks-pengikut aliran kepercayaan bertemu dalam "Kegiatan Pembinaan Umat Budha" di Kemranjen. Kegiatan tersebut menjadi media untuk membahas penyesuaian identitas, misal dalam pencatatan pernikahan yang sebelumnya hanya dilakukan di hadapan keluarga dan diresmikan oleh lingkungan dan kepala desa. Pencatatan pernikahan melalui tokoh agama menjadi penting setelah ditetapkan Undang-Undang Nomor 1 Tahun 1974 tentang Perkawinan. Sebelumnya, pada tahun 1966 terbit Ketetapan MPRS Nomor XXVII/1966 tentang Agama, Pendidikan dan Kebudayaan, yang berimplikasi pada meningkatnya kebutuhan akan guru agama pada tahun 1970-an. Suminah menyatakan: "Setelah muncul Budha, anak tidak mau mengikuti guru Islam; kita melaporkan ke dinas, anak-anak yang ijazahnya SMA diajari, dibuatkan surat tugas mengajar di sekolah; ada vihara, ada PGA, saya membuat sendiri tahun '70-an."

Berdasarkan uraian di atas, perubahan identitas agama masyarakat pedesaan wilayah Banyumas, apabila dilihat dari konsep identitas budaya [10], merupakan identitas masyarakat pedesaan yang memiliki "kesamaan sejarah maupun leluhur," identitas yang "bersifat lentur, tidak tetap, dan dapat berubah." Kesamaan yang dimiliki masyarakat tersebut adalah pada aspek budaya dan pada identitas sebagai pengikut aliran kepercayaan yang mendapatkan stereotip komunis, yang mau tidak mau harus mengubah identitasnya karena tekanan sosial dan politik.

Perubahan identitas di atas, jika dilihat berdasarkan pemikiran Berger dan Luckmann, merupakan realitas yang dikonstruksi secara sosial melalui proses dialektis antara internalisasi, objektivasi, dan eksternalisasi. Eksternalisasi dilakukan pemimpin spiritual Jawa melalui aktualisasi dan penyesuaian diri untuk kemudian diobjektivasikan terhadap masyarakat kulturalnya. Proses objektivasi pemimpin spiritual dengan makna-makna subjektif di dalamnya menumbuhkan kesadaran pada masyarakat untuk menjadi bagian dari identitas agama baru. Kemauan ini merupakan bentuk internalisasi melalui sosialisasi, sehingga masyarakat mengenal, tertarik, dan mengambil peran dalam kegiatan keagamaan, pendidikan, dan pernikahan.

Melalui proses dialektis yang terus-menerus, masyarakat eks-pengikut aliran kepercayaan membangun identitas baru sebagai umat Buddha. Identitas agama baru ini merupakan hasil produksi masyarakat sekaligus keagenan individu yang mengonstruksi identitas baru masyarakatnya. Dengan demikian, perubahan identitas sebagai dampak sosial politik tahun 1965 merupakan proses menjadi yang tidak pernah selesai (becoming) [14] yang dialami masyarakat Banyumas dari penganut aliran kepercayaan menjadi umat Budha. Identitas baru menjadi umat Budha bagi eks-penganut aliran kepercayaan merupakan upaya mengambil posisi (positioning) ketika konflik sosial politik terjadi pada akhir masa Orde Lama hingga Orde Baru. Upaya tersebut juga dilakukan dalam rangka mencari perlindungan, melawan stereotip komunis pasca-G30S, serta menghindari tekanan sosial dari masyarakat. 


\section{Simpulan}

Perubahan identitas dengan menjadi umat Budha merupakan realitas sosial yang diciptakan oleh penganut aliran kepercayaan dalam konteks sosial mereka. Politik agama dan konflik politik era Orde Lama hingga Orde Baru menjadi penyebab utama adanya konversi agama atau perubahan identitas tersebut. Konversi agama juga merupakan upaya pemosisian (positioning) oleh masyarakat Jawa untuk mencari perlindungan, melawan stereotip komunis, dan menghindari tekanan sosial. Alasan masyarakat pengikut aliran kepercayaan memilih agama Budha dilatarbelakangi oleh peran tokoh atau sesepuh kelompok yang berperan sebagai agensi, di samping karena kesamaan budaya, sejarah, dan leluhur.

\section{Referensi}

[1] Patty Sa. Aliran Kepercayaan: A Socio-Religious Movement In Indonesia - ProQuest. Washington State University, ProQuest Disertations Publishing; 1986.

[2] Mulder JAN. Aliran Kebatinan as an Expression of the Javanese worldview. J Southeast Asian Stud. 1970;1((2)):105-14.

[3] Ricklefs M. The birth of the abangan. Bijdr tot Taal-, Land- en Volkenkd. 2006;162(1):35.

[4] Nurwanti YH, Harnoko D, Larasati TA. Sejarah Perkembangan Ekonomi dan Kebudayaan di Banyumas Masa Gandasubrata Tahun 1913-1942. Yogyakarta: Balai Pelestarian Nilai Budaya (BPNB); 2015. 30-31 p.

[5] Endraswara S. Agama Jawa: Ajaran, Amalan, dan Asal-Usul Kejawen. Edisi Revi. Yogyakarta: Narasi; 2018. 5 p.

[6] Priyadi S. Beberapa Karakter Orang Banyumas. J Bhs Dan Seni. 2003;31(1):19.

[7] Kantor Sensus \& Statistik Propinsi Daerah Tingkat I Jawa Tengah. Jawa Tengah Selayang Pandang 1978. Semarang: Kantor Sensus \& Statistik Propinsi Daerah Tingkat I Jawa Tengah; 1987. $159 \mathrm{p}$.

[8] Bimbingan Masyarakat Buddha Kantor Wilayah Provinsi Jawa Tengah Kementerian Agama Republik Indonesia. No Title. Semarang; 2019.

[9] Hendro M, Soedartno, Daryono, Suhandono, Soetrisno, Soegimin E al. Jawa Tengah Selayang Pandang 1982. Semarang: Kantor Statistik Propinsi Jawa Tengah; 1982. 280 p.

[10] Hall S. Cultural Identity and Diaspora: Identity: Community, Culture, Difference. In: Rutherford J, editor. Identity: Community, Culture, Difference. Lawrence \& Wishart; 1990. p. 225.

[11] Berger PL. LT. The Social Construction of Reality: A Treatise in the Sociology of Knowledge. England: Penguin Books; 1991. 79 p.

[12] Badan Pusat Statistik Kabupaten Banyumas. Kabupaten Banyumas Dalam Angka 2010. Purwokerto: Badan Pusat Statistik Kabupaten Banyumas; 2010. 120 p.

[13] Ricklefs MC. Mengislamkan Jawa: Sejarah Islamisasi di Jawa dan Penentangnya dari 1930 sampai Sekarang. 2013;184-97.

[14] Hall S. Cultural Identity and Diaspora: Identity: Community, Culture, Difference. Rutherford J, editor. Lawrence \&; 1990. 226 p. 